\title{
Analysis of Students' and Parents' Satisfaction through Service Quality at Al-Amjad Islamic School Medan
}

\author{
Fadhullah $^{1}$, Darwin Sitompul ${ }^{2}$, Isfenti Sadalia ${ }^{2}$ \\ ${ }^{1,2}$ Master of Management Study Program on Postgraduate School of University of Sumatera Utara \\ Corresponding Author: Fadhullah
}

\begin{abstract}
Education is an important aspect of life. The more developed the world and the increasing population causes an increasing number of educational institutions, both formal and nonformal sectors. Parents are also increasingly selective in choosing the right education for their children. The growth of educational institutions are also affecting each of institution to planning and implementing a perfect formula in order to make them better than competitors or in other words called as competitive advantages for having satisfaction that were dreamed of customers. The purpose of this research is to find out that service quality consists of reliability, assurance, tangibles, empathy, and responsiveness are affecting to customers satisfaction in Al-Amjad Islamic School Medan where the intended consumers are parents and students. Data collection are taken using questionnaires and analyzed with multiple linear regression analysis method. Research shows that service quality with reliability, assurance, tangibles, empathy, and responsiveness variables has positive and significant effect to customer's satisfaction. Partially, each of variable assurance and responsiveness also has positive and significant effect to customer's satisfaction. The variables of reliability, tangibles, and empathy have positive effect to customer's satisfaction but not significant based on partial test. Assurance is the dominating variable to customer satisfaction in Al-Amjad Islamic School Medan.
\end{abstract}

Keywords: customer satisfaction, service quality

\section{BACKGROUND}

Education is an important aspect of life. The development of the world and the population growth that is getting faster, of course, have various impacts on education. The more developed the world and the increasing population causes an increasing number of educational institutions, both formal and non-formal sectors. Parents are also increasingly selective in choosing the right education for their children. Every educational institution must compete in increasing the satisfaction of students and parents as users of educational services.

Satisfaction is one of the goals of service companies that must be achieved, because satisfaction will encourage customers to continue to use the services we offer, and will also help create loyalty and word of mouth from satisfied customers. Creating customer satisfaction is not necessarily like turning the palm of the hand nor can it be created instantly. There are various factors driving the realization of customer satisfaction. One of these factors is how the quality of services provided by an educational institution to users of educational services or in this case parents and students. According to Kasmir (2009), good service quality is the company's ability to provide services that can provide satisfaction to customers with predetermined standards. This capability is shown by the human resources and the facilities and infrastructure they have. 
Al-Amjad Islamic School is one of the educational institutions located in the city of Medan. It starts from Playgroup, Kindergarten, Elementary School, and Junior High School. Al-Amjad Islamic School was founded in 2010 and started running its business operations in the 2016/2017 academic year. Based on student admission data from 2016 to 2019, AlAmjad Islamic School could not meet the expected student targets.

\begin{tabular}{|c|c|c|c|}
\hline & Academic Year 2016/2017 & Academic Year 2017/2018 & Academic Year 2018/2019 \\
\hline Total Student Capacity & 716 & 716 & 716 \\
\hline Total Target & 650 & 520 & 460 \\
\hline Total Realization & 534 & 433 & 449 \\
\hline Gap Total & $-17.84 \%$ & $-16.73 \%$ & $-2.44 \%$ \\
\hline
\end{tabular}

Based on a survey conducted on students' parents on July-August 2018, the issue of satisfaction on school services is one of the important factors that must be considered which is an indication of a decline in student enrollment each year.

\section{Services Quality}

Tjiptono (2011) states that service quality is a function of customer expectations for purchases, in the process of providing the quality received and on the quality of the output received. So that the definition of service quality can be interpreted as an effort to fulfill the needs and desires of consumers and the accuracy of its delivery in balancing consumer expectations. Meanwhile, Lupiyoadi (2006) argues that service quality is the overall characteristics and characteristics of a product or service in terms of its ability to meet predetermined needs. While the opinion of Kasmir (2009) that good service quality is the company's ability to provide services that can provide satisfaction to customers with predetermined standards. This capability is shown by the human resources and the facilities and infrastructure they have.

\section{Reliability}

Hoffman and Bateson (2010) argue that reliability is: how a company can be relied on and consistent in carrying out its operational activities, does the company continue to serve consumers without discriminating against these consumers, and whether the company continues to keep its promises, or always tries to do its best to every customer.

\section{Assurance}

Hoffman and Bateson (2010) state that Assurance is how the competence of a company and the professionalism of a company in carrying out its operational activities. This dimension also measures how the company interacts with customers, starting from courtesy, hospitality, and how to treat customers. Security is also one part of assurance, namely how a company is able to provide security for its customers.

\section{Tangibles}

Tangibles (physical evidence) in the opinion of Hoffman and Bateson (2010) is compares customer expectations with what customers feel about the company's ability to manage physical evidence in service delivery. Physical evidence of a service includes many things, starting from architecture, design, layout, lamps, tables, brochures, room comfort, to the appearance of employees, and other things that represent how a company operates.

\section{Empathy}

Empathy in Hoffman and Bateson (2010) is which looks at how a company understands what customers want, how a company is able to understand the wants and demands of customers, and tries to fulfill them. This dimension measures whether a company is able to think properly as it is a customer who has various needs and wants to be fulfilled. 


\section{Responsiveness}

Hoffman and Bateson (2010) explain about the responsiveness of the company in providing services to customers. Are the services provided by the company as expected based on time, are employees often indifferent to customers, and how does the company deal with customers who need service at the same time.

\section{Customer satisfaction}

The final stage in marketing is how to create post-purchase behavior that benefits the company. One of them is customer satisfaction. Supranto (2006) states that "companies must be able to provide satisfaction to their customers, for example by providing products of better quality, lower prices, faster product delivery and better service than their competitors." Opinion of Gerson (2002) customer satisfaction is "the customer's perception that their expectations of a product or service have been met or exceeded. Satisfied customers will do business with you more and more often. The more satisfied a customer is, the more money he spends, and the company's profits will be even greater."

\section{Conceptual framework}

Chotivanich (2014) in his research stated that the customer-perceived service quality, the customer satisfaction, and the customer loyalty were at high levels. The causal structural equation modeling of the loyalty showed influential relationships among the latent variable components, in which the service quality demonstrated no direct influence on loyalty to Thai Airways' domestic flights, but instead held an indirect influence through the satisfaction factor. The satisfaction factor, as implied, directly influenced the customer loyalty. This implied that, the service quality improvement would positively affect customer satisfaction and hence maintain their loyalty. Based on previous research, a conceptual framework can be drawn up as follows:

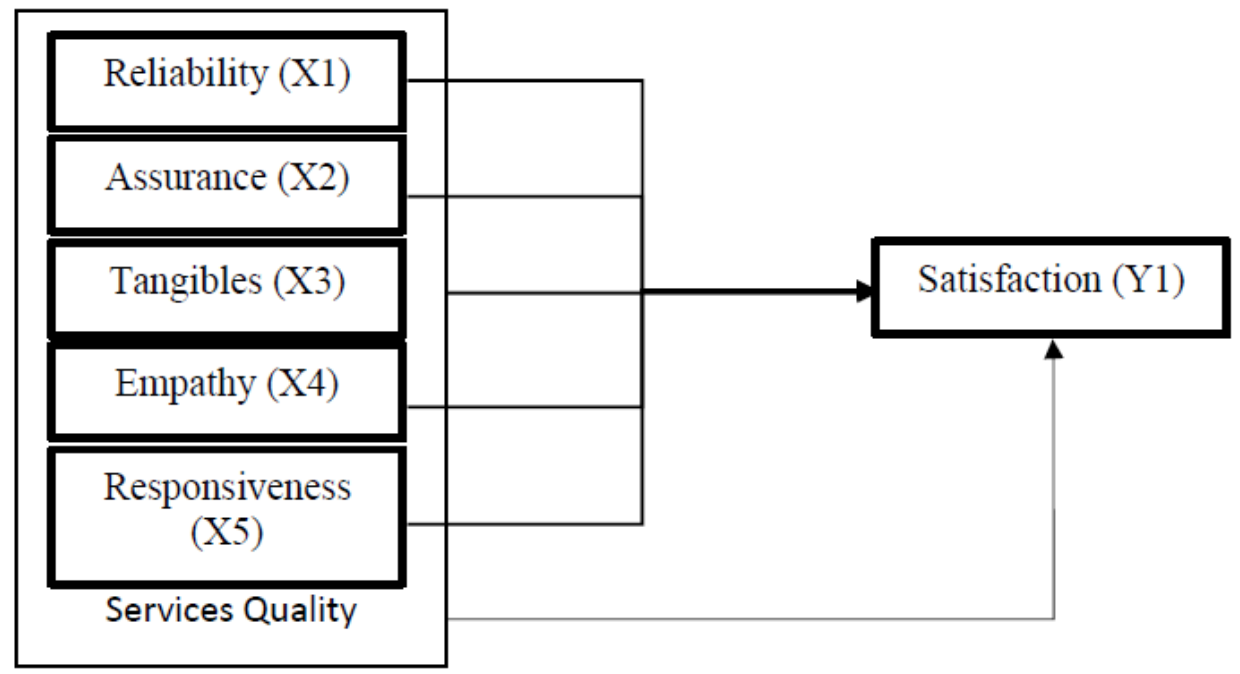

Figure 1. Conceptual framework

\section{Hypothesis}

The hypothesis in this study is that service quality consisting of reliability, assurance, tangibles, empathy, and responsiveness has a positive and significant effect on customer satisfaction at Al-Amjad Islamic School, Medan.

\section{RESEARCH METHODOLOGY}

This type of research is an associative explanatory research, which is research that aims to determine the relationship between two or more variables (Kurniawan, 2012). The variables connected in this study are the variable reliability (X1), assurance (X2), tangibles (X3), empathy 
(X4), and responsiveness (X5) to customer satisfaction (Y). This study uses a quantitative approach to the type of survey research. Data were collected through interviews and questionnaires obtained from primary data sources, namely from the AlAmjad Islamic School then processed using multiple linear regression analysis to determine the effect of service quality dimensions, namely reliability, assurance, tangibles, empathy, and responsiveness on customer satisfaction at Al-Amjad Islamic School, Medan.

The population in this study were all parents / guardians of each student at the AlAmjad Islamic School, totaling 1155 students. The sample size was determined using the Slovin formula as many as 92 respondents. The researcher will use simple sampling and random sampling techniques to collect primary data through interviews and questionnaires where the researcher will meet and select a sample directly from the population that accidentally meets.

\section{RESULTS AND DISCUSSION Simultaneous Test (F test)}

Simultaneous test (F test) was conducted to determine whether the independent variables consisting of reliability, assurance, tangibles, empathy, and responsiveness variables had a joint influence on the dependent variable, namely satisfaction at Al-Amjad Islamic School. The hypothesis model used is: H0: b1 b2 b3 b4 b5 = 0 which means the variables reliability, assurance, tangibles, empathy, and responsiveness do not have a joint effect on the dependent variable, namely satisfaction.

Tabel 2. Simultaneous Test

\begin{tabular}{l} 
Tabel 2. Simultaneous Test \\
\begin{tabular}{|l|l|l|l|l|l|c|}
\hline \multicolumn{7}{|l|}{ ANOVA $^{\text {a }}$} \\
\hline Model & Sum of Squares & df & Mean Square & F & Sig. \\
\hline \multirow{2}{*}{1} & Regression & 368.604 & 5 & 73.721 & 29.345 & $.000^{\mathrm{b}}$ \\
\cline { 2 - 7 } & Residual & 216.049 & 86 & 2.512 & & \\
\cline { 2 - 7 } & Total & 584.652 & 91 & & & \\
\hline
\end{tabular} \\
\hline
\end{tabular}

The results of the simultaneous test ( $\mathrm{F}$ test), which shows that the value of $\mathrm{F}$ count is 29.345 which is greater than F-table of 2.48, then the significance value of 0.000 is less than 0.05 so that it can be concluded that simultaneously or together all the independent variables, namely reliability, assurance, tangibles, empathy, and responsiveness have a positive and significant effect on the dependent variable, namely satisfaction. The results of this study concluded that satisfaction can be increased with better service quality in terms of the dimensions of reliability, assurance, tangibles, empathy, and good responsiveness.

\section{Partial Test ( $t$ test)}

Tabel 3. Partial Test

\begin{tabular}{|c|c|c|c|c|c|c|}
\hline \multicolumn{7}{|c|}{ Coefficients $^{\mathrm{a}}$} \\
\hline \multirow{2}{*}{\multicolumn{2}{|c|}{ Model }} & \multicolumn{2}{|c|}{ Unstandardized Coefficients } & \multirow{2}{*}{$\begin{array}{l}\text { Standardized Coefficients } \\
\text { Beta }\end{array}$} & \multirow{3}{*}{$\begin{array}{l}\mathbf{t} \\
-.406\end{array}$} & \multirow{3}{*}{$\begin{array}{l}\text { Sig. } \\
.686 \\
\end{array}$} \\
\hline & & \multirow{2}{*}{$\begin{array}{l}\text { B } \\
-.784 \\
\end{array}$} & \multirow{2}{*}{$\begin{array}{l}\text { Std. Error } \\
1.932\end{array}$} & & & \\
\hline 1 & (Constant) & & & & & \\
\hline & Reliability & .076 & .103 & .069 & .744 & .459 \\
\hline & Assurance & .385 & .110 & .376 & 3.489 & .001 \\
\hline & Tangibles & .058 & .123 & .051 & .474 & .637 \\
\hline & Empathy & .073 & .105 & .088 & .695 & .489 \\
\hline & Responsiveness & .342 & .109 & .324 & 3.149 & .002 \\
\hline
\end{tabular}

From the results of the partial test it can be seen that the regression model is:
$Y=a+b 1 \times 1+b 2 \times 2+b 3 \times 3+b 4 \times 4+b 5 \times 5$

$+\mathrm{e}$ 
$\mathrm{Y}=-0.784+0.076 \mathrm{x} 1+0.385 \times 2+0.058$

$\mathrm{x} 3+0.073 \times 4+0.342 \times 5+\mathrm{e}$

Satisfaction $=-0.784+0.076$ reliability + 0.385 assurance +0.058 tangibles +0.073 empathy +0.342 responsiveness $+\mathrm{e}$

Thus the effect of each variable is:

1. The variable reliability has a positive but insignificant effect on satisfaction as seen from the t-count value of 0.744 which is smaller than 1.662 and the significance of 0.459 is greater than 0.05 .

2. The assurance variable has a positive and significant effect on satisfaction, which can be seen from the t-count value of 3.498 which is greater than
1.662 and the significance of 0.001 is less than 0.05 .

3. Tangibles variable has a positive but insignificant effect on satisfaction as seen from the t-count value of 0.474 smaller than 1.662 and the significance of 0.637 greater than 0.05 .

4. The empathy variable has a positive but insignificant effect on satisfaction as seen from the t-count value of 0.695 which is smaller than 1.662 and the significance of 0.498 is greater than 0.05 .

5. The responsiveness variable has a positive and significant effect on satisfaction as seen from the t-count value of 3.149 which is greater than 1.662 and the significance of 0.002 is less than 0.05 .

\section{Determination Coefficient Test $\left(\mathbf{R}^{2}\right.$ test)}

Tabel 4. Determination Coefficient Test $\left(\mathbf{R}^{2}\right.$ test $)$
\begin{tabular}{|l|l|l|l|l|}
\hline Model Summary & \\
\hline Model & R & R Square & Adjusted R Square & Std. Error of the Estimate \\
\hline 1 & $.794^{\mathrm{a}}$ & .630 & .609 & 1.58499 \\
\hline
\end{tabular}

The $R$ value is 0.794 , which means that the relationship between the independent variables (reliability, assurance, tangibles, empathy, and responsiveness) is closely related to the dependent variable (satisfaction). The adjusted $\mathrm{R}$ Square value is 0.609 or $60.9 \%$, which means that $60.9 \%$ satisfaction is determined by the quality of service and its five dimensions, while the other $39.1 \%$ is determined by other variables not examined in this study. Then the standard error of estimate figure shows the number 1.58499 which shows the model is good because the number is small.

\section{The Effect of Variable Assurance on Customers Satisfaction.}

The results showed that the assurance variable (assurance) had a positive and significant effect on satisfaction as seen from the t-count of 3.498 which was greater than 1.662 and the significance was 0.001 less than 0.05 . The results of this study indicate that an increase in the assurance variable will increase the satisfaction of the parents of students at the Al-Amjad Islamic School. Based on the results of the questionnaire it was also known that there were 21 respondents $(22.8 \%)$ who answered neutral and 2 respondents $(2.2 \%)$ answered that they did not agree that the learning provided was as promised. This shows that the guarantee variable is one of the variables that must be considered in more depth.

\section{The Effect of Tangibles Variables on Customers Satisfaction.}

The results showed that the tangibles variable had a positive but insignificant effect on satisfaction as seen from the tcount value of 0.474 smaller than 1.662 and the significance of 0.637 greater than 0.05 . These results indicate that physical evidence can increase consumer satisfaction even though not directly because the parents of students are more demanding of the values their children will get academically and in character, not only from good physical evidence. These results also indicate that 
currently the parents of students are satisfied with the physical evidence possessed by the Al-Amjad Islamic School where the facilities, facilities and infrastructure are very supportive of a good and comprehensive learning process.

\section{The Influence of the Empathy Variable on Customers Satisfaction}

The results showed that the empathy variable had a positive but insignificant effect on satisfaction as seen from the $t$ count value of 0.695 which was smaller than 1.662 and the significance of 0.498 was greater than 0.05 . The results of this study indicate that empathy can increase the satisfaction of the parents of students, but not directly because there are other variables that are more dominant in influencing customer satisfaction. The results of this study indicate that the empathy shown by all elements of Al-Amjad Islamic School will provide a sense of being cared for, a sense of indifference, and a sense of security and comfort for each parent so that they will feel satisfied with the satisfaction of the parents of students.

\section{The Effect of Variable Responsiveness to Customer Satisfaction}

The results showed that the responsiveness variable had a positive and significant effect on satisfaction as seen from the t-count value of 3.149 which was greater than 1.662 and the significance was 0.002 less than 0.05 . These results indicate that the satisfaction of the parents of students at Al-Amjad Islamic School can increase if responsiveness is increased.

\section{CONCLUSION}

1. Service quality is measured using the variables reliability, assurance, physical evidence, empathy, and responsiveness simultaneously have a positive and significant effect on customer satisfaction at Al-Amjad Islamic School, Medan.

2. Partially, the assurance variable and responsiveness variable each have a positive and significant effect on customer satisfaction at Al-Amjad Islamic School, Medan.

3. Partially, the variable reliability (reliability), physical evidence (tangibles), and empathy (empathy) each have a positive but insignificant effect on consumer satisfaction at Al-Amjad Islamic School, Medan.

4. Variable assurance (assurance) is the most dominant variable affecting consumer satisfaction at Al-Amjad Islamic School in Medan and must be considered seriously because it is closely related to consumer satisfaction and learning which is the main core of Al-Amjad Medan Islamic School.

Acknowledgement: None

\section{Conflict of Interest: None}

\section{Source of Funding: None}

\section{REFERENCES}

1. Chotivanich, Piyakanit. 2014. Service Qualitym Satisfaction, and Customer Loyalty in Full-Service Domestic Airline in Thailand. International Journal of Arts \& Sciences. ISSN. 1944-6934.

2. Gera, Rajat. 2011. Effects of Online Service Quality Dimensions on Satisfaction, Value, and Behavorial Outcomes. International Journal of Arts \& Sciences. ISSN. 19446934

3. Gerson, Richard. F. 2002. Mengukur Kepuasan Pelanggan. Jakarta: Penerbit PPM.

4. Ghozali, Imam. 2011. Aplikasi Analisis Multivariate dengan Program IBM SPSS. Edisi Kelima. Universitas Diponegoro. Semarang

5. Hermawan, Dadang. 2016. A Study on Stikom Bali's Student Satisfaction Levels on Service Education. Researchers WorldJournal of Arts, Science \& Commerce. ISSN. 2231-4172.

6. Hoffman, K. Douglas and John E.G Bateson, 2011. Services Marketing: Concepts, Strategies \& Cases. Fourth Edition. Cengage Learning. USA 
7. Kanwal, F and Rehman, M. 2016. Measuring Information, System and Service Qualitites for the evaluation of e-learning systems in Pakistan. Pakistan Journal of Science Vol 68 No. 3

8. Kuncoro, Mudrajad. 2003. Metode Riset untuk Ekonomi dan Bisnis. Jakarta: Erlangga.

9. Kurniawan, Benny. 2012. Metodologi Penelitian. Jelajah Nusa. Tangerang.

10. Lupiyoadi, Rambat dan Hamdani A. 2006. Manajemen Pemasaran Jasa Edisi 2, Jakarta : Salemba Empat.

11. Mukhtar, Umer. et. al. 2015. Factors Affecting the Service Quality Of Public And Private Sector Universities Comparatively: An Empirical Investigation. Researchers World- Journal of Arts, Science \& Commerce. ISSN. 2231-4172.

12. Sekaran, Uma. 2003. Research Methods for Business Fourth Edition. New York: John Wiley and Sons, Inc.

13. Sugiyono. 2012. Metode Penelitian Bisnis. Bandung: CV. Alfabeta

14. Supranto, J. 2006. Pengukuran Tingkat Kepuasan Pelanggan - Untuk Menaikkan Pangsa Pasar. Jakarta: Rineka Cipta

15. Tjiptono, Fandy. 2011. Manajemen Pemasaran Jasa. Malang: CV. Bayumedia.
16. Umar, Husein.2003. Riset Pemasaran \& Perilaku Konsumen. Gramedia Pustaka Utama, Jakarta.

17. Setiawan, Muhammad Edwin dan Zeplin Jiwa Husada. 2017. Analisis Peningkatan Kualitas Pelayanan Pendidikan dan Prestasi Belajar pada Program LSP di SMK X Sidoarjo. Seminar dan Konferensi Nasional IDEC 2017. ISSN : 2579-6429. Pp 29-38

18. Rachmad. 2012. Analisis Kualiats Pelayanan terhadap Kepuasan Siswa SMA Negeri 1 Pangkalpinang menggunakan metode Servqual dan Importance Performance Analysis. Universitas Terbuka Pangkal Pinang.

19. Hanggara, Fuad Dwi, Sugiono, Remba Yanuar Efranto. 2017. Analisis Kualitas Layanan berbasis Servqual terintegrasi dengan metode QFD.

20. https://www.cnnindonesia.com/nasional/201 41211140014-20-17509/standar-pelayanansekolah-dasar-dan-menengah-masih-minim

How to cite this article: Fadhullah, Sitompul D, Sadalia I. Analysis of students' and parents' satisfaction through service quality at Al-Amjad Islamic School Medan. International Journal of Research and Review. 2021; 8(5): 231-237. DOI: https://doi.org/10.52403/ijrr.20210531 